\title{
POSIBILIDAD Y NECESIDAD \\ DE UNA NARRATIVA MARXISTA. METARRELATOS, POSMODERNIDAD, HISTORIAS SUBALTERNAS*
}

\author{
Jorge Polo Blanco** \\ polo@espol.edu.ec
}

RESUMEN En el presente trabajo pretendemos abordar una problemática que tiene que ver con aquella hipótesis, erigida en corazón de la posmodernidad, que sostenía la radical imposibilidad de construir metarrelatos capaces de hallar un sentido último del devenir histórico. Como corolario de lo anterior, habríamos asistido a una radical deslegitimación del marxismo como teoría capaz de proveer verdadero conocimiento histórico y, por ende, también habría quedado desacreditado como programa político de emancipación. Ubicado como uno de los grandes relatos de la modernidad europea que ya no tendrían nada que ofrecer, y defenestrado como ideología salvifica, el marxismo debe sin embargo dialogar con esa misma crítica para mostrar que todavía tiene legítima potencia a la hora de narrar con sentido (pero también con validez epistémica) algunas de las más determinantes subyugaciones que atenazan a buena parte de la humanidad.

Palabras clave Marxismo, posmodernidad, metarrelato, violencia epistémica, historias subalternas.

ABSTRACT In this paper, we intend to address a problematic which has to do with the hypothesis, established at the very heart of postmodernity, which

* Artigo submetido em 18/05/17. Aceito em 02/08/17.

** Escuela Superior Politécnica del Litoral. Guayaquil - Equador.

KRITERION, Belo Horizonte, n 140, Ago./2018, p. 495-509 
maintained the radical impossibility of constructing meta-narratives capable of discovering an ultimate meaning of historical evolution. As a corollary of the above, we would have witnessed a radical delegitimation of Marxism as a theory capable of providing true historical knowledge and how it would also therefore have been discredited as a political programme for emancipation. Viewed as one of the great accounts of European modernity which would therefore have nothing to offer, and dismissed as a salvific ideology, Marxism must, nonetheless, dialogue with this criticism in order to show that it still possesses real potential when it comes to narrating meaningfully (but also with epistemic validity) some of the most decisive subjugations which affect much of the human race.

Keywords Marxism, postmodernity, metanarrative, epistemic violence, subaltern histories.

\section{El marxismo, un metarrelato presumiblemente desacreditado}

Si es cierto que el capitalismo clásico (industrial y fordista) empezó a disolver todo lo sólido en el aire, como señalaran Marx y Engels en su celebérrimo "Manifiesto", tal vez las sociedades de mercado ultraconsumistas de la segunda mitad del siglo XX modularan en un cierto sentido la culminación de aquella descomunal crisis decimonónica. Ese régimen cultural que ha venido a denominarse posmodernidad, por lo tanto, habría emergido en la matriz misma de un capitalismo postfordista, desorganizado y extremadamente flexible (Polo Blanco, 2010). Buena parte de las instituciones sociales antaño férreas, empezaron a quedar licuadas, deslegitimadas y corroídas (Sennett, 2013). Fredric Jameson ha sido el principal sustentador de tal diagnóstico: "Creo que el surgimiento del posmodernismo se relaciona estrechamente con el de este nuevo momento del capitalismo tardío, de consumo o multinacional. Creo también que sus rasgos formales expresan en muchos aspectos la lógica más profunda de ese sistema social particular" (1985, p. 185). Uno de tales rasgos sería, por cierto, "la desaparición de un sentido de la historia" (Ibíd.), el surgimiento de formas de vida intensamente mercantilizadas y espectacularizadas (Debord, 2003) y, por ello mismo, cada vez más instaladas en una suerte de presente perpetuo desconectado de todo pasado. Pero Jameson, presentando la posmodernidad como la "lógica cultural del capitalismo tardío", se pregunta en un momento dado si, a pesar de ello, no puede haber algo así como una posmodernidad de resistencia. "Hemos visto que hay una manera en la que el posmodernismo replica o reproduce -refuerza- la lógica del capitalismo de consumo; la cuestión 
más significativa es si existe también una manera en la que resiste esa lógica" (1985, p. 186). Es ésta una cuestión decisiva, a saber, inquirir si acaso puede una sensibilidad posmoderna, desde sus coordenadas intelectuales, construir algún tipo de oposición crítica al despliegue imperial y triunfal del capitalismo mundializado. Esta pregunta tiene muchísima relevancia, entre otras cosas porque el marxismo ha sido uno de los principales metarrelatos atacados y desacreditados por el "pensamiento débil" de la posmodernidad.

Enemigo visceral de toda tentación hegeliana, el imaginario posmoderno no puede concebir la posibilidad de hallar una racionalidad última que dé cuenta de la totalidad del devenir histórico. Porque eso que dio en llamarse posmodernidad consistió, precisamente, en la cancelación de cualquier tentativa de buscar (y desvelar) un único sentido en los entresijos del despliegue universal de la Historia (Racionero, 1997). Semejante postulado de "unidad de sentido" ejercería una brutal violencia contra la contingencia de lo múltiple; pero, a su vez, tal violencia de orden teórico podría llegar a producir efectos de orden práctico no del todo deseables, al generar determinadas imágenes y representaciones de lo histórico. Lo cual se podría sintetizar de la siguiente forma: las explicaciones teóricas totalizadoras darían paso, irremediablemente, al totalitarismo político. Y es por todo ello que la postulación de un único sujeto colectivo, depositario de una verdad última y portador asimismo de la auténtica emancipación de la humanidad entera (sujeto autoconsciente, homogéneo y monolítico), tampoco sería ya posible (ni deseable). Jean-François Lyotard (1996) así lo aseveraba: "El marxismo, último vástago nacido del cristianismo y de las Luces, parece haber perdido todo poder crítico" (p. 55). Y, un poco después, sentenciaba que "el espectro se ha desvanecido llevándose consigo el último gran relato crítico, lejos de la escena histórica" (p. 56). Un diagnóstico tan contundente y demoledor, empero, tendría que ser revisado. La tesis más fuerte de Lyotard, a saber, la que dictamina que la lectura marxista de la historia ha perdido todo poder crítico, quizás merezca ser revisitada y cuestionada.

Aquella misma pregunta -la que se refiere a la posibilidad de una "posmodernidad de resistencia"- aparece también en David Harvey, inquieto por los efectos políticos de la impugnación posmoderna a todos los grandes relatos.

¿Tiene [el posmodernismo] un potencial revolucionario a causa de su oposición a todas las formas del meta-relato (incluyendo el marxismo, el freudismo y todas las formas de la razón de la Ilustración) y su preocupación por «otros mundos» y «otras voces» tan largamente silenciados (mujeres, gays, negros, pueblos colonizados con sus propias historias)? ¿O se trata simplemente de la comercialización y domesticación del modernismo, y de una reducción de las aspiraciones ya gastadas de este último a un laissez-faire, a un eclecticismo mercantil del «todo vale»? (1998, p. 59). 
El propio Harvey da una respuesta clara y meridiana:

Lo peor de todo es que si bien el pensamiento posmodernista abre una perspectiva radical al reconocer la autenticidad de otras voces, cierra inmediatamente el acceso de esas otras voces a fuentes más universales de poder, al guetificarlas dentro de una otredad opaca, la especificidad de este o aquel juego de lenguaje [...] El juego de lenguaje de una trama de banqueros internacionales puede ser impenetrable para nosotros, pero eso no lo pone a la par del lenguaje igualmente impenetrable de los negros de los centros urbanos, desde el punto de vista de las relaciones de poder (Ibid., p. 138).

Si todos los juegos del lenguaje flotan, en efecto, en una misma equivalencia indiferenciada, porque todo es pura construcción discursiva sin anclaje real, entonces jamás podremos articular alguna crítica fundada en la localización epistémica de asimetrías estructurales reales; no podremos organizar ningún sistema teórico que desentrañe las actuales relaciones económico-políticas. No podremos, por ejemplo, conocer las causas de la pobreza o inquirir la genealogía plausible de cruentas situaciones de dominio y sometimiento.

Es notorio y significativo que incluso en el universo de la intelectualidad socialista occidental se produjera una paulatina renuncia a comprender en clave materialista las nuevas prácticas culturales. Abandonando todas las premisas economicistas del viejo marxismo, alejándose del materialismo histórico y abjurando del proletariado como sujeto histórico revolucionario, los nuevos críticos marxistas de la cultura bascularon hacia nuevas cuestiones y problemáticas sociales relacionadas con el género, la raza, la ecología o la estética. Así lo expresará Perry Anderson:

El marxismo occidental, como hemos visto, desde 1920 se inhibió cada vez más de abordar teóricamente los grandes problemas económicos o políticos. Gramsci fue el último de sus pensadores que trató directamente en sus escritos problemas fundamentales de la lucha de clases. Sin embargo, tampoco él escribió nada sobre la economía capitalista en sí, en el sentido clásico de analizar las leyes del movimiento de este modo de producción. Después de él se produjo un silencio similar con respecto al orden político de la dominación burguesa y al modo de derrocarlo. El resultado fue que el marxismo occidental en su conjunto, cuando fue más allá de cuestiones de método para considerar problemas de sustancia, se concentró casi totalmente en el estudio de las superestructuras. Además, los órdenes superestructurales específicos por los que mostró un interés mayor y más constante fueron los más alejados de la base material, de la base económica, según expresión la de Engels. En otras palabras, no fueron el Estado o el Derecho los que le proporcionaron los objetos típicos de su investigación. Lo que concentró el foco de su atención fue la cultura (1978, p. 94).

El centro de gravedad dentro de la tradición marxista se fue desplazando, progresivamente, hacia la "crítica cultural" de la sociedad burguesa contemporánea, abandonando (o tratándolos únicamente de forma secundaria) todos los ejes 
teóricos relacionados con la propiedad de los medios de producción, las clases sociales, la explotación laboral y, en definitiva, dejando de lado todo aquello que tenía que ver más directamente con las estructuras socioeconómicas.

En su desconexión con la praxis revolucionaria de la clase obrera, la teoría marxista se fue tornando más "filosófica”, más epistemológica, más académica y esotérica; sus motivos temáticos acabaron orientándose, de manera significativa, hacia la crítica estética. En definitiva, los campos teóricos más importantes para la tradición clásica del materialismo histórico fueron quedando paulatinamente relegados en los márgenes del pensamiento marxista. El acta de defunción de este (antaño) poderoso corpus teórico fue esgrimida por muchos, incluso ya antes de la caída del Muro. "No critico el socialismo en aras de otras ideas; lo que digo es que no es ya más que un fantasma y que ha dejado de convencer y de movilizar a las masas. Algunos retóricos hablan aún del auge del socialismo y de las luchas obreras. En realidad, la era del socialismo ha finalizado. Urge percatarse de ello y vivir con nuestro tiempo, pensar y actuar en función de las nuevas situaciones y de los nuevos comportamientos en medio de los cuales actuamos, y que parecen cruzar como sonámbulos los herederos equivocados de las luchas y de las teorías pretéritas" (Touraine, 1982, p. 218). Se podía decretar ya, como vemos que hizo Alain Touraine, el advenimiento de una era irreversiblemente postsocialista. También Gilles Lipovetsky señaló que el marxismo perdió la batalla porque, sencillamente, las grandes epopeyas no tenían ya cabida en el imaginario dominante. "La fuerza de los dispositivos subpolíticos del consumismo y la moda generalizada es lo que ha causado la derrota del heroísmo ideológico-político de la modernidad" (2006, p. 64). El culto a la felicidad privada y un egotismo recreativo sin limitaciones promueven la des-politización galopante de las masas; el sacrificio y la abnegación, exigidos por el compromiso con la causa ideológico-política, desfallecen en medio del flujo consumista y hedonista. La utopía de un futuro emancipado retrocede, definitivamente, ante la celebración lúdica del inmediato presente. Como corolario ineludible de semejante diagnóstico, quedaría establecido que el marxismo -como praxis, como discurso y, en definitiva, como herramienta analítica- habría perdido ya toda pertinencia.

Ralf Dahrendorf, por otro lado, destacó el presunto error del "teorema de la lucha de clases", señalando que tal lucha no había conducido a una polarización radical de la sociedad capitalista que constituyera la contradicción última de la misma, hasta el punto de hacer implosionar al sistema para dar paso a otro distinto (y mejor). De hecho, y muy contrariamente a lo diagnosticado por el marxismo, el fenómeno de la lucha de clases (inicialmente disruptivo, anómico, a-legal y virulento) había ido encontrando buen acomodo en el interior 
del sistema social. Se trataba, en suma, de una institucionalización paulatina del antagonismo de clase. La tensión entre capital y trabajo, que desde una óptica marxista constituía la inextirpable gran contradicción de la sociedad capitalista (contradicción interna que, tarde o temprano, acabaría sellando su propio final), dicha tensión, decimos, habría sido canalizada, amortiguada y regulada por normativas previsibles. Capital y trabajo negocian, finalmente, dentro de unas reglas del juego bien marcadas, sin quiebra alguna del sistema, y con ello la lucha de clases ha perdido todo su potencial de desestabilización política general e "incluso la idea de un partido obrero industrial ha perdido su sentido político" (Dahrendorf, 1962, p. 307). El conflicto laboral, por lo tanto, habría quedado enteramente despolitizado; la lucha sindical ya no se erige en una plataforma de impugnación holística y anti-sistémica. Y en un contexto semejante, el marxismo tendría ya muy poco que decir; de hecho, no tendría nada que relatar. Nosotros, sin embargo, queremos rebatir semejante tesis.

\section{La posmodernidad como lógica cultural del capitalismo tardío}

La posmodernidad, desde luego, comparte los anteriores diagnósticos; para ella, el marxismo es un metarrelato exangüe y fenecido. Pero puede establecerse otro giro, tras verificar esos desplazamientos, y preguntar si acaso se ha de renunciar a una comprensión materialista de la propia condición posmoderna. Porque esa misma posmodernidad que nos hace renunciar a toda construcción teórica totalizante (toda vez que ya no existirían fundamentos teóricos verdaderamente fiables) es producida, ella misma, por el tránsito a una nueva modulación del régimen de acumulación capitalista; y es esto último lo que ella, desde sus presupuestos, no puede aprehender. David Harvey lo explica bien:

Los filósofos posmodernistas no sólo nos dicen que aceptemos sino que disfrutemos de las fragmentaciones y de la cacofonía de voces a través de las cuales se entienden los dilemas del mundo moderno. Obsesionados con la deconstrucción y la desautorización de cualquier forma de argumento que se les oponga, pueden terminar condenando sus propios reclamos de validez hasta que no quede ninguna base para la acción razonada. [El posmodernismo] rechaza la clase de metateoría que puede explicar los procesos económico-políticos (flujos monetarios, divisiones internacionales del trabajo, mercados financieros etc.) que son cada vez más universalizantes por la profundidad, intensidad, alcance y poder que tienen sobre la vida cotidiana (1998, p. 137).

El posmodernismo podría terminar renunciando a toda comprensión del presente, pues de esa cacofonía deshilachada de "voces diversas" y "discursos flotantes" no querría extraer ningún conocimiento articulado y totalizador. "La retórica 
del posmodernismo es peligrosa en la medida en que se niega a enfrentar las realidades de la economía política y las circunstancias del poder global" (Ibíd., p. 138). Pero, y como nos sigue diciendo Harvey: "La meta-teoría no puede ser exonerada" (Ibíd.). Porque el "gran relato" del liberalismo económico no ha declinado, e incluso ha devenido como la indestructible religión monoteísta del Mercado (Hinkelammert, 2001); los "mercados libres", en efecto, han terminado siendo un "reemplazo de la divinidad" (Jameson, 2003, p. 323). Al parecer, es ésa la única metanarrativa que no ha sucumbido en el marasmo posmoderno. En un contexto así, por lo tanto, quizás no sea del todo razonable renunciar por completo a la construcción de una teoría comprehensiva y crítica que denuncie los fundamentos de dicho metarrelato (el del mercado capitalista global) y desvele las relaciones de dominio que justifica y promueve.

Según nos quiso enseñar cierta perspectiva posmoderna, apenas podemos seguir hablando de un estado de alienación generalizada; ese concepto pertenecería a un mundo ya periclitado. El sujeto ya no estaría alienado (como todavía podría observar una teoría crítica más clásica), sino fragmentado. $\mathrm{Si}$ el sujeto ha sido desmembrado y desarticulado esquizofrénicamente, si su experiencia temporal ha perdido toda continuidad coherente entre pasado, presente y futuro (refundiéndose en una experiencia temporal deshilvanada, en una serie destartalada de presentes puros y desvinculados), entonces este sujeto (que en verdad no es tal) apenas puede configurarse como una identidad perdurable; no hay sustento para un proyecto existencial estable, significativo y duradero. ¿Quién puede resultar alienado, si no hay propiamente sujeto?

\footnotetext{
Ya no podemos concebir al individuo como alienado en el sentido clásico marxista, porque estar alienado supone un sentido del propio ser coherente y no fragmentado, del que se está alienado. Es sólo en función de este sentido centrado de identidad personal como los individuos pueden realizar proyectos en el tiempo [...] Pero es característico del posmodernismo cancelar esa posibilidad y concentrarse en las circunstancias esquizofrénicas a las que dan lugar la fragmentación y todas las aquellas inestabilidades (incluidas las del lenguaje) que nos impiden proyectar estrategias para producir un mundo radicalmente diferente (Harvey, 1998, p. 71).
}

Pero la sensibilidad posmoderna, regodeándose lúdicamente en esa situación de pura fragmentación, celebrada además como un liberador triunfo de lo múltiple sobre lo uno, de la diversidad polimorfa sobre la monolítica unidad, del devenir sobre la opresiva quietud, en medio de esa celebración de la pluralidad fragmentada y descentrada, insistimos, la sensibilidad posmoderna puede llegar a renunciar a la elaboración de toda investigación teórica y crítica de las causas socioeconómicas e histórico-materiales que, presumiblemente, están en las raíces de esa lúdica fragmentación esteticista. Esto es, la posmodernidad no está en 
condiciones de comprenderse a sí misma; sus propios presupuestos bloquean y cortocircuitan tal posibilidad.

\section{Una narrativa marxista sí es posible y necesaria en el siglo XXI}

Alex Callinicos afirmó, en un ensayo donde criticaba con ardor la noción misma de "posmodernidad", que el capitalismo no había sufrido una transformación cualitativa esencial; no nos habíamos adentrado, ni mucho menos, en una era post. En verdad, estábamos sumergidos en el capitalismo de siempre. "No creo que vivamos en una «nueva era», en una era «postindustrial y postmoderna» fundamentalmente diferente del modo capitalista de producción que ha dominado el mundo durante los dos siglos anteriores" (1994, p. 25). Pero, a pesar de semejante aseveración, el propio Callinicos no deja de registrar que toda la "cháchara posmoderna" es el síntoma de alguna suerte de mutación (Ibid., p. 27). ¿Pero de qué fue síntoma la erupción de la cultura posmoderna? He ahí una pregunta que, en cualquiera de los casos, debe ser formulada. Lo que la posmodernidad cancela, como ya vimos, es la posibilidad de encontrar un único sentido (o siquiera algún sentido) en el despliegue temporal de las sociedades humanas; y es ahí donde podemos hallar alguna clave relevante.

Contra cualquier constructo de tipo hegeliano, el "talante" posmoderno no puede concebir el hallazgo de un sentido unificador que racionalice la totalidad del devenir histórico de la civilización humana (entre otras cosas, podría señalar un buen pensador posmoderno, porque no existe ningún sujeto histórico al que podamos designar con la etiqueta "civilización humana"). Es decir, el discurrir de los asuntos colectivos no puede ser aprehendido como una trama lógicamente engarzada. "Ahora bien, formuladas así las cosas, la acentuación de la contingencia histórica ofrece la inmediata consecuencia de romper con el postulado de la unidad de la historia" (Racionero, 1997, p. 203). Y esa ruptura es celebrada por la posmodernidad, porque la postulación de "unidad de sentido" (en la interpretación de los procesos históricos) siempre ejerció una brutal violencia contra la contingencia de lo múltiple, como ya habíamos señalado; una violencia teórica que, sin embargo, bien podía llegar a producir desastrosos efectos prácticos (sociopolíticos) al generar determinadas imágenes de lo que el proceso histórico había sido y podría llegar a ser. Porque, concluía Quintín Racionero,

la interpretación de los hechos que hace el historiador influye en el desarrollo de la historia misma [...] Historiar supone, en efecto, según el punto de vista que estamos adoptando, elegir entre secuencias de sentido que se saben plurales y contingentes, a partir de combinatorias concretas de hechos. Pero mientras que es importante insistir 
en que tal elección no proporciona verdad a aquellas secuencias ni necesidad a estas combinatorias, en cambio sí determina, o puede hacerlo, la actualización y promoción de ciertas posibilidades en vez de otras distintas, condicionando con ello el futuro a través de imágenes propiciadas por la convicción histórica (1997, p. 213).

Ahora bien, la posmodernidad ni siquiera puede concebir, en su versión más extremista, la posibilidad de esbozar un criterio que sirva de hilo conductor a la hora de comprender el sentido de las dinámicas históricas; esto es, sumergida en la apoteosis de la fragmentación puede desembocar en una renuncia a toda configuración de sentido, aunque ésta asuma todas las cláusulas de la contingencia. No hay Historia (escrita con hache mayúscula); existen historias plurales e inconexas, fragmentos inconmensurables de tiempo, pedazos deshilachados y microscópicos que no pueden ser introducidos en un relato unificador sin ejercer, con ello, una injustificable violencia epistémica (con peligrosas derivaciones de violencia práctica). Desde luego, tal diagnóstico puede conllevar una saludable advertencia contra los innegables peligros que laten bajo cualquier forma de filosofía de la historia. Pero una posmodernidad llevada al límite puede deslizarse hacia otro peligro no menor, a saber, el hundimiento de lo histórico en el reino de lo inefable.

Gianni Vattimo, en ese sentido, destacaba "la disolución de la idea de historia como curso unitario; no hay una historia única, hay imágenes del pasado propuestas desde diversos puntos de vista, y es ilusorio pensar que haya un punto de vista supremo, comprensivo, capaz de unificar todos los restantes [...]" (1996, p. 76). Ese resquebrajamiento de la concepción de una Historia perfectamente coherente y unitaria vendría determinado por el advenimiento de la "sociedad de la comunicación".

Hoy se nos habla mucho de la posmodernidad, es más, tanto se habla que casi ha llegado a convertirse en algo obligado distanciarse de este concepto, considerarlo una moda pasajera, declararla una vez más un concepto «superado»...Pues bien, yo considero, al contario, que el término posmoderno sí tiene sentido, y que tal sentido se enlaza con el hecho de que la sociedad en la que vivimos sea una sociedad de la comunicación generalizada, la sociedad de los mass media (Ibíd., p. 75).

En tal sociedad, hipercomunicada hasta el paroxismo, se produciría una multiplicación exponencial de los microrrelatos, un estallido heteróclito y polimorfo de imágenes del mundo, una óptica caleidoscópica y polifónica en la que millones de voces y miradas se conjugarían en un concierto comunicativo descentralizado y multiforme; un campo de juego, y esto es lo decisivo, en el que ninguna posición (hermenéutica, epistémica o enunciativa) podría tener más importancia o preeminencia que las demás. 
En cuanto cae la idea de una racionalidad central de la historia, el mundo de la comunicación generalizada estalla es una multiplicidad de racionalidades «locales» -minorías étnicas, sexuales, religiosas, culturales o estéticas- que toman la palabra, al no ser, por fin, silenciadas y reprimidas por la idea de que hay una sola forma verdadera de realizar la humanidad, en menoscabo de todas las peculiaridades, de todas las individualidades limitadas, efímeras y contingentes (Ibíd., p. 84).

Frente a lo que pudieron sostener un Adorno o un Marcuse, Vattimo no ve en los grandes medios de comunicación de masas, o en las tecnologías de la información, un peligro de uniformización cultural que desemboque en una sociedad enteramente administrada, manipulada y controlada sino, muy al contrario, una gran oportunidad para alcanzar la liberación a través (precisamente) de esa fragmentación de los discursos y pluralización de los estilos de vida.

Pero a pesar del jubiloso optimismo que Vattimo mostraba en esa obra, hemos de preguntarnos si acaso no han emergido nuevas inflexiones nihilistas en el seno de la "sociedad de la información". Esa explosión fragmentada puede celebrarse, en efecto, como el definitivo triunfo de una pluralidad que decodifica todo cierre semántico totalitario; pero no puede perderse de vista que la construcción de todo discurso crítico empieza, de igual modo, a convertirse en una tarea quimérica. Esa "debilidad" del pensamiento posmoderno, que disfruta con la muerte de todas las ideas-fuerza y con la ausencia de fundamentos sólidos, podría desembocar en lo siguiente: la explicación de todas las violencias históricas se torna inviable; y el dolor de las víctimas, por ende, aparece como inenarrable. Es por ello que Terry Eagleton no acepta la imposibilidad de construir algún relato esclarecedor de la historia humana:

Para el pensamiento socialista, ha existido realmente un gran relato y la mayor parte es para lamentar. Es una verdad más para entristecerse que para celebrar. Sería mucho mejor si los posmodernos tuvieran razón, y no hubiera nada constante o continuo en la crónica. Pero el precio de creer en esto es una traición a los muertos, y a la mayoría de los que viven. Lo que más fuertemente conmueve en torno de la historia en este tiempo es que ha demostrado la mayor de las consistencias; para decirlo de otra manera, las fuertemente persistentes realidades de la escasez y la explotación. Por supuesto, estas cosas han tomado diferentes formas culturales. Es sorprendente ver cuántas maneras hay de ser privado y dominado, lo suficiente para mitigar el hambre posmoderna de pluralidad. Pero, si la historia fuera completamente fortuita y discontinua, ¿cómo habríamos de dar cuenta de esta persistente continuidad? (1997, p. 85).

El dominio, la explotación, la subyugación o el sometimiento de unos seres humanos a manos de otros constituyen, todos ellos, elementos que aparecen recurrentemente en las tramas humanas; he ahí un hilo conductor casi inquebrantable, una constante histórica, un núcleo de sentido identificable.

No parece, en verdad, que Eagleton esté reclamando la validez de una proposición tan clásica como aquélla que rezaba que "la historia de todas las 
sociedades que han existido hasta ahora es nada más que la historia de la lucha de clases"; no al menos con todos los componentes reduccionistas o dialécticos que ello pudiera arrostrar. Sin embargo, también se siente obligado a separarse de aquella fragmentación posmoderna que renuncia a tejer y esbozar alguna narración histórica con sentido; el socialismo, sin embargo, habría de erigirse como la posibilidad de comprender el devenir histórico de las distintas sociedades humanas a través de un mínimo relato (aunque éste no adquiera proporciones de relato único y universal). Porque es verdad que las numerosas relaciones de dominio, de explotación, de subyugación y de sometimiento se pueden narrar de muchas formas; los sujetos de tales relatos, además, son múltiples y en ocasiones híbridos. El relato socialista es sólo uno más, entrecruzado con el relato de las mujeres, de los afrodescendientes, de los indígenas, de los homosexuales. Es más, existen relatos aún más "pequeños" (pero repletos de significación) que laten dentro de éstos: el relato, por ejemplo, de las mujeres indígenas dominadas en muchos aspectos por los varones de su propia etnia; o el relato de homosexuales negros marginados dentro de la comunidad afro en la que viven. Pero, en cualquier caso, sin narración no hay comprensión; y sin comprensión no hay emancipación.

Porque si no fuera posible ya encontrar un "Galileo de la historia", tal y como hubiese pretendido Louis Althusser (1969), ello no debe llevarnos, bajo un movimiento pendular, al otro extremo posmoderno que ve en toda narración con sentido una violencia epistémica insufriblemente dogmática. Fredric Jameson, desechando toda inclinación hacia lo inenarrable, insiste en la necesidad de una narrativa marxista:

Sólo el marxismo puede darnos cuenta adecuadamente del misterio del pasado cultural, que, como Tiresias al beber la sangre, vuelve momentáneamente a la vida y recobra color y puede una vez más hablar y transmitir su mensaje largamente olvidado en un entorno profundamente ajeno a ese mensaje. Ese misterio sólo puede llevarse de nuevo a efecto si la aventura humana es una; [... Esos asuntos pueden recobrar para nosotros su urgencia original únicamente a condición de que se los vuelva a relatar dentro de la unidad de una única gran historia colectiva; sólo si, aunque sea en una forma muy disfrazada y simbólica, se los mira como participando en un solo tema fundamental -para el marxismo, la lucha colectiva por arrancar un reino de la Libertad al reino de la Necesidad-; sólo si se los aprehende como episodios vitales en una única y vasta trama inconclusa [...] En el rastreo de las huellas de ese relato ininterrumpido, en la restauración en la superficie del texto de la realidad reprimida y enterrada de esa historia fundamental, es donde la doctrina de un inconsciente político encuentra su función y su necesidad (1989, pp. 16-17).

He ahí la posibilidad -y la necesidad- de restaurar el sentido de las tramas humanas, pasadas y presentes. Enfrentándose a todos los epígonos de Lyotard, el marxismo parece seguir requiriendo, perentoriamente, de un cierto relato. Tal vez no ya un relato estrictamente mesiánico, teleológico y protagonizado 
por un único sujeto, pero sí un relato mínimamente unificador de la aventura humana; una mínima dramatización que dé cuenta de las injusticias y los crímenes, que narre etiológicamente los episodios trágicos de la desventura colectiva de muchos grupos humanos.

Jameson reivindica, en última instancia, la posibilidad y la necesidad de una hermenéutica marxista, por mucho que ésta se aleje de los viejos esquemas mecanicistas, deterministas o economicistas.

\begin{abstract}
Así, una hermenéutica marxista -el desciframiento por el materialismo histórico de los monumentos culturales y rastros del pasado- tiene que ponerse a mano con la certidumbre de que todas las obras de la historia de clases tal como han sobrevivido y se han trasmitido para poblar los diversos museos, cánones y «tradiciones» de nuestra propia época, son todas de una manera o de otra profundamente ideológicas, han tenido todas un interés creado y una relación funcional con formaciones sociales basadas en la violencia y la explotación; y finalmente que la restauración del sentido de los más grandes monumentos culturales no puede separarse de una evaluación apasionada y parcial de todo lo que es opresivo en ellas y que conoce la complicidad con el privilegio y la dominación de clase, teñido de la culpa no sólo de la cultura en particular sino de la Historia misma como una larga pesadilla (Ibíd., p. 241).
\end{abstract}

La hermenéutica marxista, por lo tanto, aparece como un ejercicio encaminado a la extracción del lado tenebroso de las formaciones sociales, a la restauración de todo el sentido genocida y sanguinario que late tras las configuraciones culturales de las que somos herederos. Una hermenéutica que, en definitiva, no deja de ser un relato tétrico acerca de cómo las distintas cristalizaciones "civilizatorias" han sido la coartada legitimadora de situaciones más ocultas de explotación y dominio; subyugaciones clasistas, desde luego, pero también racistas y heteropatriarcales. Si el marxismo puede todavía, frente a la posmodernidad, configurar un mínimo relato de la historia humana, el sentido de dicho relato no podrá dejar de ser ese reverso negativo y criminal. Un relato, en definitiva, de horror. Y deberá concluirse, préstese mucha atención a esto, que la intención de no construir ese relato es, en sí misma, un acto de complicidad con la injusticia. El hecho mismo de no relatar con solidez es un gesto teórico (y ético-político) repleto de connivencia con el crimen. Porque detrás de la fragmentación cultural posmoderna siempre subyacieron férreas lógicas económico-políticas $\mathrm{y}$, por ello mismo, quizás sea hora de poner fin a la tiranía de las "pequeñas historias" y retornar (al menos en un cierto sentido) a los "grandes relatos" (Grüner, 2002).

No se puede tratar de apelar a una reconciliación idealista de la "historia empírica" y de "la historia como sistema", por decirlo en lenguaje hegeliano. Postular una filosofia de la historia, a estas alturas, quizás resulte descabellado. Pero se trata, más humildemente, de no desterrar la posibilidad de construir un relato, siquiera sea con validez heurística, desde el cual acceder a una comprensión mínima de la praxis humana. Queda cancelada la ilusión de 
desvelar el sentido único de la Historia en su despliegue teleológico, pues tal pretensión es quimérica y peligrosa. No obstante, sí debe permanecer abierta la posibilidad de articular narraciones con sentido, esto es, con fundamento objetivo y anclaje material. Admitiendo la inextirpable contingencia de los hechos y la multiplicidad subsecuente de interpretaciones, y sabiendo que aquellos "hechos" pueden quedar insertados en diferentes constelaciones de significado, hemos de inferir de ello que dichas constelaciones significativas nunca podrán aparecer como configuraciones totalizadoras que desvelen el sentido único desplegado en el curso histórico universal. Pero, aun reconociendo lo anterior y admitiendo una irreductible pluralidad de tramas de sentido (enfrentadas polémicamente entre sí, de manera irremisible), lo que no puede quedar eliminado es la función narrativa misma. Y el marxismo, frente a algunos devaneos posmodernos que tal vez pretendieron desarticular toda escritura histórica, no puede renunciar a todo relato, a toda escritura del drama histórico; no puede, en suma, renunciar a encontrar aquellas tramas de sentido que, por muy contingentes que sean (por muy entretejidas que estén con otras tramas posibles), alumbran aspectos decisivos (aunque no únicos) del devenir histórico humano. Porque la narración siempre alberga un irrenunciable valor epistémico del que no es sensato desprenderse.

\title{
4 A modo de conclusión
}

Si el marxismo, por emplear una expresión de Walter Benjamin, hubiera de "cepillar la historia a contrapelo", una de sus tareas impostergables sería la de nombrar lo que siempre fue acallado y marginado; re-nombrar lo que quedó in-nombrado, reconstruir otras tramas de sentido obliteradas por esas tramas que erigieron (oficializaron) los vencedores de la historia (Mate, 2006). El escritor polaco Tadeusz Borowski lo expresaría de forma desgarrada en "Nuestro hogar es Auschwitz":

\begin{abstract}
Ahora sé qué elevado precio pagaron otros en la Antigüedad. ¡Qué crimen espantoso fueron las pirámides de Egipto, los templos y estatuas griegas! ¡Cuánta sangre tuvo que derramarse sobre las calzadas romanas, las fortificaciones fronterizas y los edificios de las ciudades! (2004, p. 59).
\end{abstract}

La narración desde la perspectiva de los vencidos arranca el monopolio del sentido a la gran Historia Universal, y así reaparecen experiencias y significados hurtados por la gran teodicea histórica.

Me acuerdo de cómo me gustaba Platón. Hoy sé que mentía. Porque los objetos sensibles no son el reflejo de ninguna idea, sino el resultado del sudor y la sangre de los hombres. Fuimos nosotros los que construimos las pirámides, los que arrancamos el mármol y las piedras de las calzadas imperiales, fuimos nosotros los que remábamos en las galeras y arrastrábamos arados [...] (Ibid.). 
Se trata, tal vez, de rescatar el sentido robado al trabajo humano, siempre oculto en la trastienda subterránea de la historia. Visibilizar, en último término, todo aquel dolor que pocas veces emerge (o lo hace de manera difuminada) en nuestra comprensión del pasado.

El abigarrado mosaico de las múltiples masacres no debe quedar integrado en un mismo relato unificado; los inmensos dramas (jalonados de dominaciones y subyugaciones) que han compuesto la textura de las historias humanas no deben quedar subsumidos en un mismo despliegue teleológico saturado de sentido. Porque tras ese marasmo de dolores particulares no puede aprehenderse una suerte de racionalidad inmanente que constituya algo así como el "fin último" de la Historia. Lo fáctico no puede transfigurarse de inmediato en racional, como de hecho ocurría en la filosofía de la historia hegeliana, porque entonces en dicha mega-narración quedarían sepultados multitud de aconteceres (muchos de ellos criminales y tiránicos) que, habiendo sido, quedarían empero racionalizados (esto es, justificados) y sepultados por ello mismo en el olvido; porque los vencidos y los masacrados no pueden emerger con digna presencia y con "voz propia" en el relato oficial de una historia presidida (protagonizada) por un sujeto único, por muy liberador y progresista que se autoconciba dicho sujeto.

Como señalaba Ranajit Guha, debe realizare "una re-escritura que escuche las voces bajas de la historia" (2002, p. 30), esto es, que propicie una polifonía en la que resuenen con nitidez todas aquellas voces que siempre resultaron inaudibles en la historiografía estandarizada y hegemónica. La escritura de la historia casi siempre ha revelado, en efecto, una jerarquización que determina aquello que debe ser escuchado (por ser considerado primordial, determinante y relevante) y aquello que por el contrario debe permanecer en un granítico silencio (por ser juzgado secundario, intrascendente e irrelevante). Siempre hubo, en definitiva, una historia oficial y muchas historias subalternas. Y, si bien es cierto que tal tarea no puede ya ser concebida como la construcción de una metanarrativa capaz de integrar en ella (bajo el hechizo de una dialéctica omniabarcante y teleológica) todas las determinaciones de la historia (precisamente porque no hay una, sino múltiples historias), en cambio el marxismo sí puede todavía encontrar núcleos de sentido en la compleja trama de las subyugaciones humanas. En suma, si bien ya no puede ser un metarrelato como antaño lo pretendiera, el marxismo sí ofrece elementos teóricos y hermenéuticos perfectamente válidos a la hora de comprender algunos (pero no todos, he ahí la clave) de los mecanismos más importantes que operan detrás de las relaciones de dominio hoy imperantes, contribuyendo de esa forma a otorgar voz a los secularmente silenciados. 


\section{Referencias}

ALTHUSSER, L. "Para leer El Capital”. México: Siglo XXI, 1969.

ANDERSON, P. "Consideraciones sobre el marxismo occidental”. Madrid: Siglo XXI, 1978.

BERMAN, M. "Todo lo sólido se desvanece en el aire". Madrid: Siglo XXI, 1988.

BOROWSKI, T. "Nuestro hogar es Auschwitz". Barcelona: Alba, 2004.

CALLINICOS, A. "Contra el postmodernismo. Una crítica marxista". Bogotá: Áncora, 1994.

DAHRENDORF, R. "Las clases sociales y su conflicto en la sociedad industrial". Madrid: Rialp, 1962.

DEBORD, G. "La sociedad del espectáculo". Valencia: Pre-textos, 2003.

EAGLETON, T. "Las ilusiones del posmodernismo". Buenos Aires: Paidós, 1997.

GRÜNER, E. "El fin de las pequeñas historias. De los estudios culturales al retorno (imposible) de lo trágico". Buenos Aires: Paidós, 2002.

GUHA, R. "Las voces de la historia y otros estudios subalternos". Barcelona: Crítica, 2002.

HARVEY, D. “La condición de la posmodernidad”. Buenos Aires: Amorrortu, 1998. HINKELAMMERT, F. J. "El nihilismo al desnudo. Los tiempos de la globalización". Santiago de Chile: LOM, 2001.

JAMESON, F. "Posmodernismo y sociedad de consumo". (pp. 165-186). In: La posmodernidad. Barcelona: Kairós, 1985.

. "Documentos de cultura, documentos de barbarie". Madrid: Visor, 1989.

. "La posmodernidad y el mercado". (pp. 309-328). In: Ideología. Un mapa de

la cuestión. Buenos Aires: Fondo de Cultura Económica, 2003.

LIPOVETSKY, G. "Los tiempos hipermodernos". Barcelona: Anagrama, 2006.

LYOTARD, J. F. “Moralidades posmodernas". Madrid: Tecnos, 1996.

MATE, R. "Medianoche en la historia. Comentarios a las tesis de Walter Benjamin 'Sobre el concepto de historia"'. Madrid: Trotta, 2006.

POLO BLANCO, J. "Perfiles posmodernos. Algunas derivas del pensamiento contemporáneo". Madrid: Dykinson, 2010.

RACIONERO, Q. "Postmodernidad e historia (Tareas de la investigación histórica en el tiempo de la posthistoria". Anales del Seminario de Metafísica, 31, pp. 185-216, 1997. SENNETT, R. "La corrosión del carácter. Las consecuencias personales del trabajo en el nuevo capitalismo". Barcelona: Anagrama, 2013.

TOURAINE, A. "El postsocialismo". Barcelona: Planeta, 1982.

VATTIMO, G. "La sociedad transparente". Barcelona: Paidós, 1996. 